\title{
Effects of Septoria nodorum Berk. on yield and yield com- ponents of spring wheat
}

\author{
"REIJO KARJALAINEN, "*AINO LAITINEN and TAPIO JUUTI \\ "Departments of Plant Pathology and Plant Breeding, University of Helsinki, \\ SF-00710 Helsinki 71, Finland
}

\section{*Hankkija Plant Breeding Institute, SF-04300 Hyrylä, Finland}

\begin{abstract}
Data from two experiments was analysed in order to determine the effects of Septoria nodorum Berk. on the yield of spring wheat. In the first experiment the cultivar Hankkija's Taava was artificially inoculated with low spore concentration suspensions of S. nodorum. The resulting disease reduced grain yield by $10 \%, 1000$-grain weight by $14 \%$, and hectolitre weight by $5.7 \%$. An examination of the ears from the main stems revealed that the pathogen induced a reduction in all yield components but especially in grain number/ear and grain weight.

In the second experiment a total of 28 cultivars or lines were studied and the correlation between grain yield/ear and disease severity was found to be negative but low. No consistent trend among the correlations was seen and some susceptible cultivars suffered only slightly from the disease while other fairly resistant cultivars showed great losses.

The results are discussed in relation to compensatory mechanisms and potential disease tolerance in wheat.
\end{abstract}

\section{Introduction}

Septoria nodorum Berk., the cause of glume blotch disease of wheat, is a major wheat pathogen in many parts of the world (SHIPTON et al. 1971). Numerous reports have shown that the glume blotch disease has rapidly increased in importance in recent years causing severe reductions in wheat yields (EYAL 1981). The reason for this trend seems to be partly explained by the fact that local wheat cultivars have been replaced with short, highyielding susceptible varieties over large areas and these varieties facilitate outbreaks of the disease (SAARI and WILCOXSON 1974, RAJARAM and DUBIN 1977). Simultaneously there have been changes in cultivation practices such as the use of minimum tillage which promotes the epidemiological build-up of inoculum; wheat stubble being an important source of primary inoculum for disease development (HARROWER 1974, JENKYN and KING 1977). Moreover, the reduced use of crop rotation and the increased use of 
fertilizers may have also contributed to the occurrence of Septoria epidemics in many intensive wheat growing areas (EYAL 1981).

S. nodorum attacks wheat at all growth stages, and can infect all aerial parts of the plant (BAKER 1978). The relationship between symptom expression and yield reductions is not consistent since the pathogen is capable of causing considerable yield reduction even at a moderate level of infection (BRÖNNIMANN 1968, SHIPTON 1968, OBST 1977). The effect of early infection by this pathogen on final yield reduction may be more important than has previously been expected. Early infection may disturb tillering and influence the primary development of the ear thus reducing the potential number of sites for assimilate deposition and consequently reducing yield (SCHAREN and TAYLOR 1968).

Considerable empirical evidence indicates that major yield losses occur when infection takes place at later development stages (BRÖNNIMANN 1968, SPIERZ 1973, WAFFORD and WHITBREAD 1978). This has been explained by the observed fact that the greatest increase in dry weight of wheat grain occurs when photosynthetic assimilates are translocated to the ear after its emergence (WOOLHOUSE 1981, LUPTON 1982). Numerous experiments show that $S$. nodorum not only causes a heavy reduction in the rate of photosynthesis but also reduces the duration of the green-leaf-area period (SCHAREN and KRUPINSKY 1969, SPIERZ 1973, WAFFORD and WHITBREAD 1976). Hence the infection causes a decreased supply in the amount of assimilates that can be translocated to the grain, and may thus reduce $1000-$ grain weight (SPIERZ 1973).

Precise estimates of national crop losses due to glume blotch disease are poorly known, but in England and Wales national surveys have revealed yield losses of up to $8 \%$ in years when infection was severe (KING 1977), and the economic significance of the disease has been shown to be important (DOODSON 1981). In Finland no estimates of the economic importance of $S$. nodorum are available, but there is every reason to assume that during the last few rainy years it has caused significant yield and quality reductions (KARJALAINEN and LAITINEN 1982).

The present paper reports on the effect of infection by S. nodorum on the yield and yield components of spring wheat.

\section{Materials and Methods}

The data reported in this study were based on two trials carried out at the experimental farm of the Hankkija Plant Breeding Institute. The objective of the first trial was to study the effects of $S$. nodorum on yield and yield components using Hankkija's spring wheat cultivar Taava.

Normal plant breeding plots $\left(8 \mathrm{~m}^{2}\right)$ with four replications arranged in a randomized block design were used. Standard fertilization and herbicide treatments were applied.

The first experiment consisted of the following treatments: uninoculated control, plots inoculated with $S$. nodorum, and plots sprayed with three 
kinds of fungicides. The following fungicide treatments were performed: spraying before anthesis with $2 \mathrm{~kg} / \mathrm{ha}$ Benlate, with $2 \mathrm{~kg} / \mathrm{ha}$ Maneb, and with a mixture of Benlate $0.25 \mathrm{~kg} / \mathrm{ha}+$ Maneb $2.4 \mathrm{~kg} / \mathrm{ha}$ respectively, and spraying at the postfloral stage with Benlate $1 \mathrm{~kg} / \mathrm{ha}$.

Three inoculations with $S$. nodorum were carried out starting before flag leaf emergence. The final treatment was made after anthesis. The inoculum consisted of about $10^{4}$ spores $/ \mathrm{ml}$. The preparation of inoculum and the culturing techniques of the fungus have been previously described in detail (KARJALAINEN et al. 1983). After inoculation all plots were irrigated to keep them wet, thus encouraging a successful disease build-up. The assessment of the disease on the different plots was made on the flag leaf and ear of 40 randomly labelled stems by estimating the percentage area covered by $S$. nodorum lesions. The assessment was made two weeks after the last inoculation.

The second experiment consisted of a variety test carried out with small plots to screen spring wheat cultivars for $S$. nodorum resistance. The details of the experiments have been previously described (KARJALAINEN et al. 1983). The purpose of this study was to examine the relationship between disease severity and yield loss (g/ear yield). Before harvesting the labelled tillers were cut and the yield components were counted. After harvesting the 1000 -grain weight was determined. The percentages of diseased area (leaf area values of the wheat leaves) were transformed using the arc-sin transformation. Variance analysis for comparing the yield between different treatments was calculated. Regression analysis, correlation analysis, and Path-coefficient analysis were also calculated according to LI (1975) in order to define the main effects caused by $S$. nodorum on yield and yield components.

\section{Results}

\section{Efects of inoculation on yield and yield components}

Artificial inoculation with low concentration of Septoria nodorum reduced grain yield by $10 \%$ and 1000 -grain weight by $14 \%$ (Table 1 ). Inoculation also induced reduction in hectolitre weight $(5.7 \%)$. All fungicide treatments caused statistically significant yield increases: $21-30 \%$ relative to the untreated control (Table 1). The fungicide treatments increased 1000grain weight and hectolitre weight.

The results of the data recorded of the single tillers are presented in Table 2. Inoculation reduced all yield components; the loss in ear yield was $38.5 \%$, in grain number/ear $17.8 \%$, in 1000-grain weight $28.4 \%$, and in spikelet number/ear $4.4 \%$. The fungicide treatment increased all the yield components recorded (Table 2). 
Table 1. Effects of artificial inoculation with low spore concentration on the yield, maturation time, 1000-grain weight and hectolitre weight of the spring wheat cultivar Hankkija's Taava in comparison to wheat grown in untreated control and fungicide treated plots.

\begin{tabular}{|c|c|c|c|c|c|}
\hline Treatment & $\mathrm{kg} / \mathrm{ha}$ & ratio & $\begin{array}{l}\text { Growth time } \\
\text { days }\end{array}$ & $\begin{array}{c}1000-\mathrm{GW} \\
\mathrm{g}\end{array}$ & $\begin{array}{c}\text { Hectolitre } \\
\text { weight } \\
\text { kg }\end{array}$ \\
\hline Untreated & 2610 & 100 & 109 & 37.5 & 68.9 \\
\hline $\begin{array}{l}\text { Septoria-inocul. } \\
\text { Benlate } 2 \mathrm{~kg} / \mathrm{ha} \text { and }\end{array}$ & 2350 & 90 & 107 & 32.3 & 65.0 \\
\hline $\begin{array}{c}1 \\
\text { Maneb } 2 \mathrm{~kg} / \mathrm{ha} \text { and }\end{array}$ & 3370 & $129^{\text {*ns? }}$ & 109 & 40.4 & 70.0 \\
\hline $\begin{array}{l}\text { Ben. } 1 \mathrm{~kg} / \mathrm{ha} \\
\text { Ben. } 0.25 \mathrm{~kg} / \mathrm{ha}+\end{array}$ & 3380 & $130^{\text {क* }}$ & 110 & 40.4 & 70.3 \\
\hline Man. 2.4 & $\begin{array}{c}3150 \\
\text { F } 20.96^{\text {해해 }}\end{array}$ & $121^{\text {Hस/ }}$ & 109 & 41.0 & 70.5 \\
\hline
\end{tabular}

Table 2. Effects of artificial inoculation with low spore concentration on the yield components of the spring wheat cultivar Hankkija's Taava in comparison to wheat grown in untreated control and fungicide treated plots.

\begin{tabular}{lcccc}
\hline Treatment & Yield/ear & $\begin{array}{c}1000- \\
\text { GW }\end{array}$ & Grain number/ear & $\begin{array}{c}\text { Spikelet } \\
\text { number/ear }\end{array}$ \\
\hline Untreated & 1.09 & 36.43 & 30.16 & 14.90 \\
Septoria-inoculation & 0.67 & 26.10 & 24.79 & 14.24 \\
Maneb 2 kg/ha + Benlate 1 kg/ha & 1.26 & 40.04 & 31.51 & 15.03 \\
LSD 0,05 & 0.30 & 9.43 & 4.17 & 5.02 \\
\hline
\end{tabular}

\section{Relationship between disease severity and yield loss}

In order to test which yield components were most affected by disease stress a correlation analysis was computed. The results of the data based on single tillers obtained from the yield loss trial are presented in Table 3. The relationship between yield ( $\mathrm{g} / \mathrm{ear})$ and ear severity is negatively significant $(\mathrm{r}=0.36, \mathrm{p}<0.05)$, and the correlation between yield and flag leaf severity is negative but weak. The ear yield seems to be most strongly correlated with grain number/ear $(r=0.71, p<0.001)$, and 1000-grain weight $(r=0.57$, $\mathrm{p}<0.01$ ). The yield component and disease severity data was subject to pathanalysis in order to partition the correlation coefficients into direct and indirect effect. The path-analysis clearly reveals that grain number/ear and 1000 grain weight had major direct effects on the yield/ear on a single tiller basis (Fig. 1). The path-diagram not only indicates that disease directly reduces grain yield but also indirectly reduces grain number and grain weight. It also shows that grain number and grain weight had the largest direct contribution to grain yield. 
Table 3. Correlation coefficients between disease severity and yield components. The data is based on single tillers taken from the yield loss trial.

Yield/ear Ear Septoria Leaf Septoria 1000-GW Spikelet

\begin{tabular}{llllll} 
Ear Septoria & $-0.36^{*}$ & & & & \\
Leaf Septoria & -0.26 & $0.48^{*}$ & & & \\
1000 - GW & $0.57^{* *}$ & -0.21 & -0.26 & & \\
Spikelet number/ear & $0.34^{*}$ & $-0.31^{*}$ & -0.11 & -0.26 & \\
Grain number/ear & $0.71^{* * *}$ & $-0.37^{*}$ & -0.26 & 0.00 & $0.58^{* *}$ \\
\hline
\end{tabular}

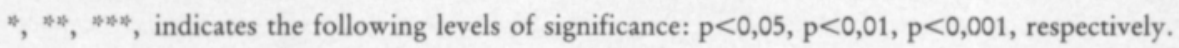

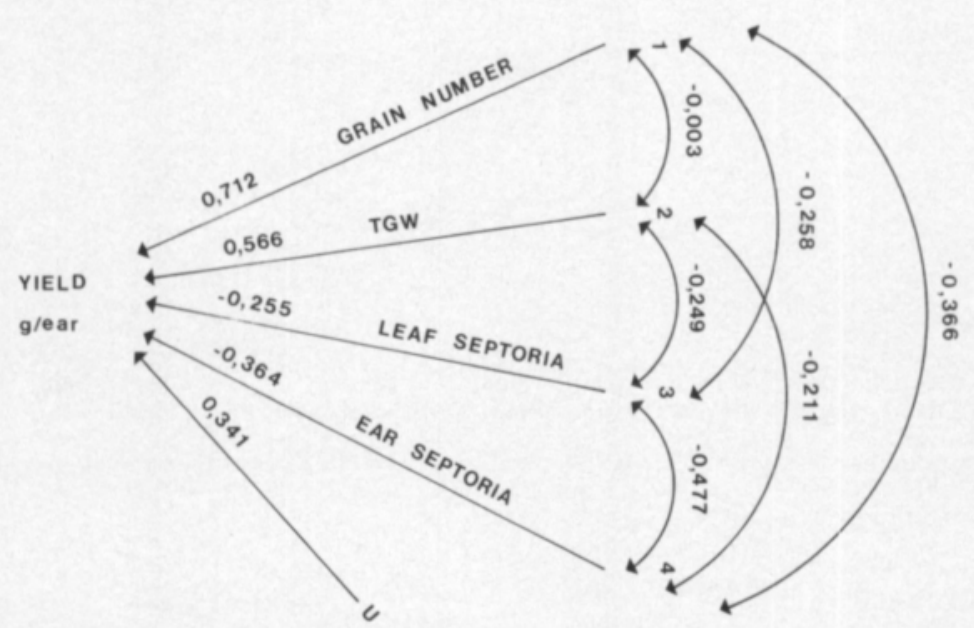

Fig. 1. Path-coefficient analysis of disease severity and yield components. The data is based on single tillers taken from the yield loss trial.

Table 4. Correlation coefficients between disease severity and yield components. The data is based on single tillers taken from small plot trials of 28 different cultivars and lines of spring wheat.

\begin{tabular}{lllccc}
\hline & Yield/ear & $1000-\mathrm{GW}$ & $\begin{array}{c}\text { Grain } \\
\text { number/ear }\end{array}$ & $\begin{array}{c}\text { Spikelet } \\
\text { number/ear }\end{array}$ & Leaf Septoria \\
\hline $1000-G W$ & $0.46^{* *}$ & & & & \\
Grain number/ear & $0.59^{* *}$ & $-0.38^{*}$ & & & \\
Spikelet number/ear & $0.39^{*}$ & -0.09 & $0.56^{* *}$ & & \\
Leaf Septoria & $-0.34^{*}$ & -0.24 & -0.09 & $-0.32^{*}$ & \\
Ear Septoria & -0.22 & $-0.43^{*}$ & 0.14 & -0.07 & $0.55^{* * *}$ \\
\hline
\end{tabular}

The results of the data recorded from 29 cultivars are presented in Table 4. The correlation between ear yield and disease severity is negative, but the coefficients are low. A detailed demonstration of the relationship between disease severity and ear yield on different cultivars is shown in Figures 2,3 \& 
4. Figure 4 demonstrates the combined disease rating (flag leaf value + ear value) in relation to yield loss calculated from the difference between noninoculated and inoculated plots. The greatest losses were detected in Ulla, Ruso, Tapio, Tähti, Kadett, Drabant, Allen, Maris Butler and CI 13406. The

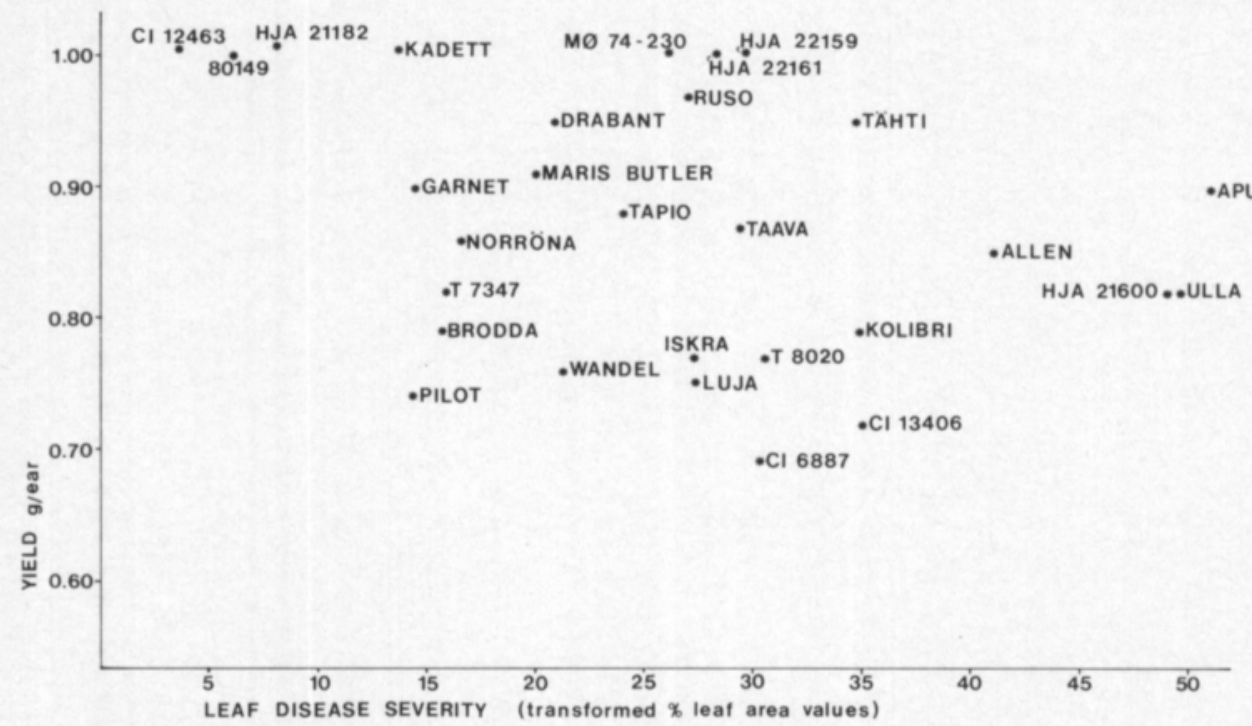

Fig. 2. Relationship between leaf disease severity and yield/ear for 28 cultivars and lines of spring wheat.

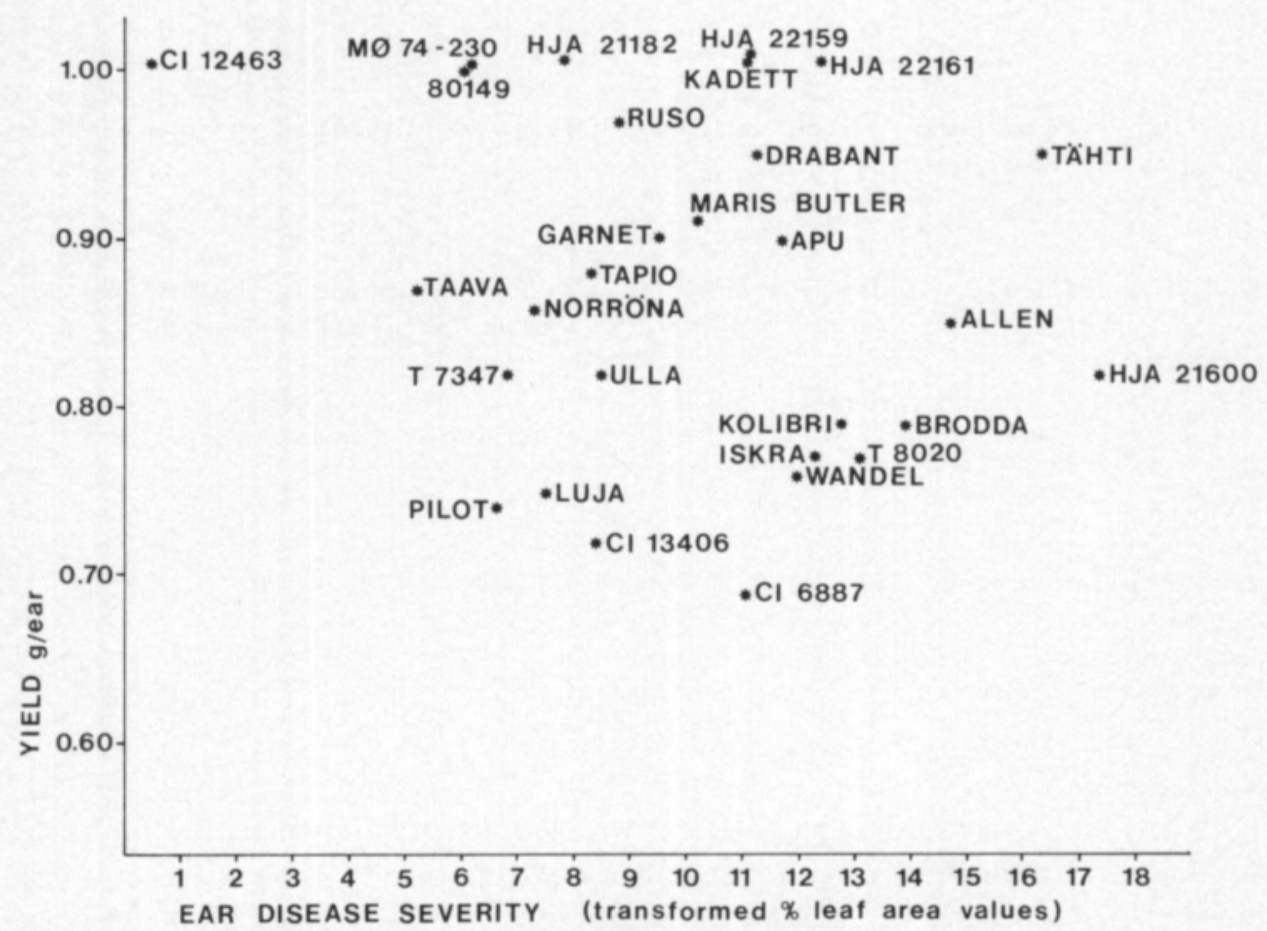

Fig. 3. Relationship between ear disease severity and yield/ear for 28 cultivars and lines of spring wheat. 
smallest reductions in yield were found in Norröna, 80149, CI 12463, T8347, Hja 22159, Hja 21600 and $\mathrm{Hja} 21182$.

A path-diagram was also constructed from the data on cultivar trials (Fig. 5). The results confirm the previous findings (Fig. 1) since again grain number and grain weight had major direct effects on the total yield/ear and the effects on total yield/ear due to disease were of the same magnitude. However, only half of the total variation is accounted for by these variables.

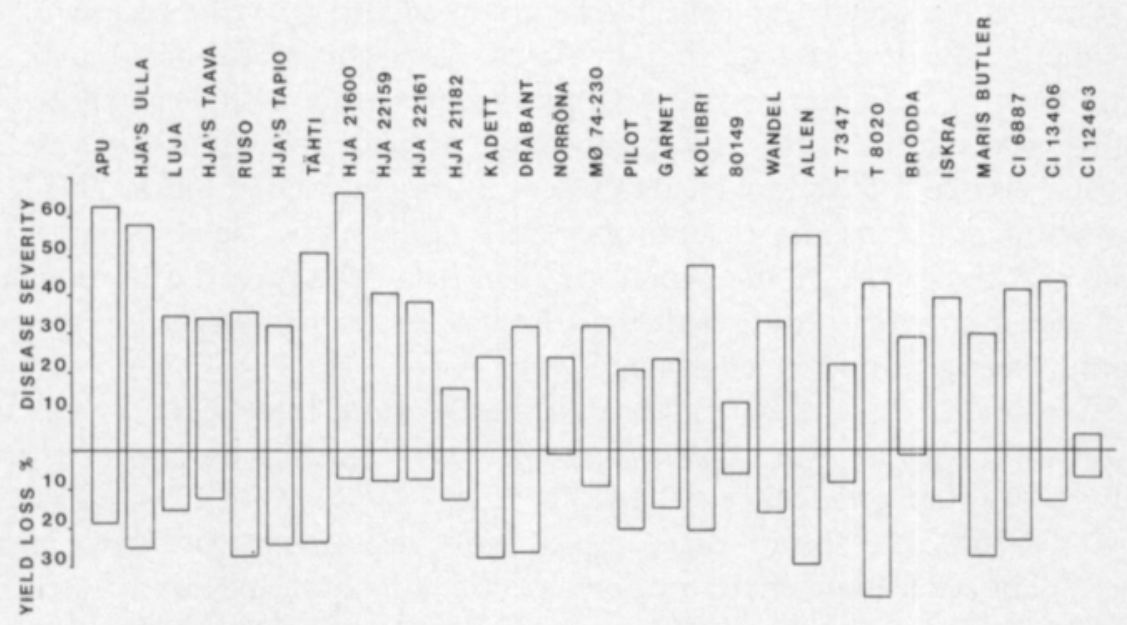

Fig. 4. Combined disease rating (flag leaf value + ear value) in relation to yield loss calculated as the difference between non-inoculated and inoculated plots. The data is based of 28 cultivars and lines of spring wheat.

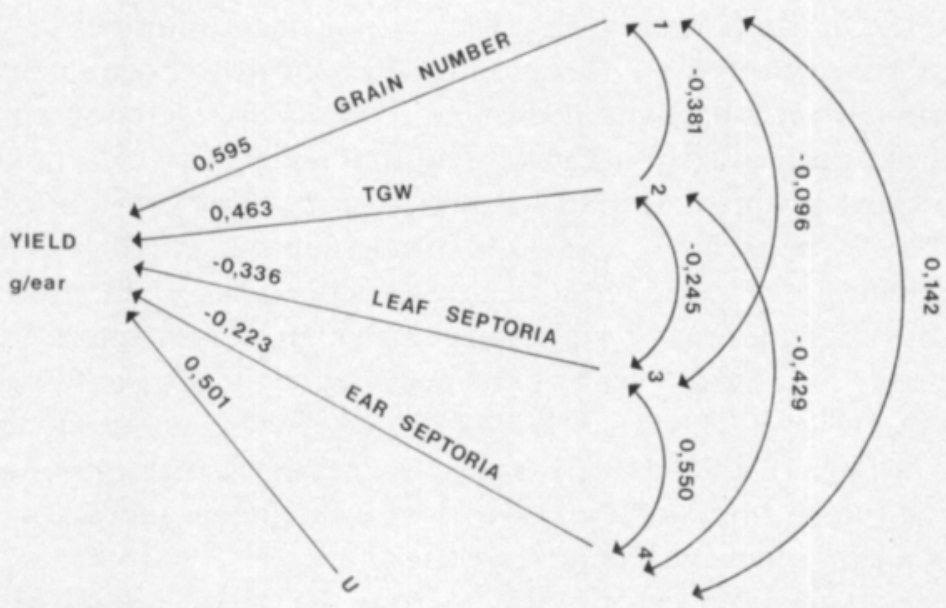

Fig. 5. Path-coefficient analysis of disease severity and yield components. The data is based on single tillers taken from small plots of 28 different cultivars and lines of spring wheat. 


\section{Discussion}

The present experiments support the prevailing idea that Septoria nodorum can cause significant yield reduction even with a moderate level of infection (OBST 1977). The results reported here show a yield reduction of 10 $\%$ in relation to untreated control plots using a moderately susceptible cultivar, Hja Taava (see KARJALAINEN et al. 1983). The yield component which was most affected was 1000 -grain weight, thus confirming the results of several experiments (BRÖNNIMANN 1968, SPIERZ 1973, NELSON et al. 1976). The hypotheses that $S$. nodorum causes a reduction in photosynthesis and shortens the green-leaf-area period are in accord with the results of this experiment. We found that in inoculated plots the maturation time was shorter than in the untreated control plots and further evidence can be seen from the fact that in the plots that received fungicide treatments the maturation time was $2-3$ days longer than it was in the inoculated plots. This latter observation confirms the results of SPIERZ (1973) who demonstrated that Maneb and Benomyl, or their mixtures, can delay the spread of $S$. nodorum in the wheat crop with the result that the flag leaf remains green longer and the grain-filling period is lengthened.

Physiological studies have indicated that Septoria infection may enhance translocation because it is known to accelerate the grain maturation rate and the onset of foliar senescence (SCHAREN et al. 1975). WAFFORD and WHITEBREAD (1976) have found that despite large lesions on the leaves and a reduction in total plant growth, $S$. nodorum infection appears to alter the export of assimilates from a leaf to only a limited extent, and it also seems to have only a small effect on the pattern of assimilate distribution. The results of SCHAREN et al. (1975) support this assumption since they found that the export of metabolites from Septoria-infected flag leaves did not vary greatly between control plants and inoculated plants.

The fungicide treatments caused significant yield increases in relation to untreated and inoculated plots. However, conclusions from this can only be applied to the field situation with great caution since a number of factors can affect the results of this kind of experiment. First of all, the fungicides used in this experiment only partially prevented $S$. nodorum infection since disease was observed on treated plots, too. The fungicides may also control other foliar diseases and this may lead to an erroneous interpretation of the yield reduction by $S$. nodorum (JAMES 1974, JAMES and GAUNT 1979). Furthermore fungicides may cause harmful side-effects on the plant and thus lower the yield or fungicides may have some curative properties and this may cause yield increases without preventing the occurrence of disease (FEHRMANN et al. 1978, JAMES and TENG 1979, COOKE et al. 1981). Recent findings of SMEDEGAARD-PETERSEN (1982) have also revealed that inhibition of the saprophytic fungal flora on cereal leaves with fungicides increases yield since saprophytic fungi deprive the host of energy.

The conclusion that can be drawn from the above arguments is that a comparison between inoculated and untreated control plots may be a rather reliable way to evaluate the effects of Septoria on wheat yield and this type of 
comparison may have applications to the field situation. The present results, where a yield loss of $10 \%$ was seen in the inoculated plots compared to the control plots, seem to be fairly realistic, but we emphasize that this experiment resulted in fairly low yield levels even in the control plots because of unsuitable weather conditions.

The yield component analysis showed that both 1000-grain weight and grain number/ear were heavily affected by the infection. These results agree with several experiments which have indicated that inoculation at a late developmental stage causes the greatest reduction in grain weight (JONES and ODEBUNMI 1971, WILLIAMS and JONES 1972, JONES and ROWLING 1976). These results may be explained by the observed fact that late infection mainly affects grain weight since this yield component develops later compared to other yield components which develop during early stages (TENG and GAUNT 1980).

Heavy infection seems to alter all yield components and hence reductions in the total yield of single tillers are evident. However, this experiment detected that in some tillers reduction in 1000-grain weight was compensated by more grains being filled per ear. This observation agrees with those of WAFFORD and WHITBREAD (1978) and JONES and ROWLING (1976) and their conclusion that compensatory mechanisms might be too weak after heavy infection to prevent large yield losses is also confirmed by our results (Table 2).

The present results suggest that path-analysis can be a powerful tool for analyzing the relationship between disease severity ratings and yield component factors. Constructing a path-diagram can be a clear and simple way to visualize disease effects as it partitions direct factors from indirect factors as they affect yield. For example, the present data reveals some interesting points regarding the different yield components. We found that grain number was the most important factor in determining the final yield/ear although several studies done on healthy wheat (WOOLHOUSE 1981) show that kernel weight is the biggest contributor to the final yield/ear. Our experiments seem to confirm the idea that when wheat is attacked by S. nodorum it compensates for lower kernel weight by the development of more kernels.

The hypothesis that $\mathrm{S}$. nodorum causes a reduction in yield which is not correlated with symptom expression (OBST 1977) was evaluated in this study. The results support this idea since we found that the correlation between disease severity and yield loss were low and our comparison between different cultivars with regard to yield loss in relation to disease severity shows many inconsistencies (Fig. 3). Some cultivars such as Pilot, Kadett, Drabant and Maris Butler, which have been found to be rather resistant to S. nodorum (KARJALAINEN et al. 1983), were seen in this study to suffer great yield losses. On the other hand some cultivars such as $\mathrm{Hja} 21600$ and $\mathrm{Hja}$ 22159 , which had been found to be fairly susceptible to S. nodorum (KARJALAINEN et al. 1983), were seen in this experiment to suffer only a small yield reduction.

These inconsistencies may possibly be explained by the phenomena of 
tolerance (BRÖNNIMANN 1968, 1982) however they may also be explained by experimental error since reliable yield comparisons require a large number of replications and careful disease assessment (SCOTT and BENEDIKZ 1977, GAUNT 1981). More experiments are needed to test the above assumption that some susceptible cultivars have tolerance to S. nodorum.

\section{Acknowledgements}

We are grateful to Professors Eeva Tapio and Peter Tigerstedt for critical reading of the manuscript. We thank Ms. Eila Lonka and Ms. Sinikka Karjalainen for technical assistance, and Mr. Lassi Kontula for his computer support. The English text was kindly revised by Ms. Heather MacKenzie and Ms. Sinikka Karjalainen. This work was supported by grants from the August Johannes and Aino Tiuran maatalouden tutkimussäätiö and this support is gratefully acknowledged.

\section{References}

BAKER, E. A. 1978. Septoria: the "lurking threat" to wheat yields. EPPO Bull. 8: 9-20.

BRÖNNIMANN, A. 1968. Zur Kenntnis von Septoria nodorum Berk., dem Erreger der Spelzenbräune und einer Blattdürre des Weizens. Phytopath. Z. 61: 101-146.

- 1982. Entwicklung der Kenntnisse über Septoria nodorum Berk. im Hinblick auf die Toleranzoder Resistenzzühtung bei Weizen. Neth. J. agric. Sci. 30: 47-62.

COOKE, R. J., JENKINS, J. E. E. \& KING, J. E. 1981. The deployment of fungicides in cereals. In: Strategies for the Control of Cereal Disease (eds. JENKYN, J. F. and PLUMB, R. T.), pp. 91-99. Blackwell Sci Publications, Oxford, London.

DOODSON, J. K. 1981. The economic contribution of resistant winter wheat varietes. J. natn. Inst. agric. Bot. 15: 413-420.

EYAL, Z. 1981. Integrated control of Septoria diseases of wheat. Plant Disease 65: 763-768.

FEHRMAN, H., REINECKE, P. \& WEIHOFEN, U. 1978. Yield increase in winter wheat by unknown effects of MBC-fungicides and captafol. Phytopath. Z. 93: 359-362.

GAUNT, R. E. 1981. Disease tolerance - an indicator of threshold? Phytopath. 71: 915-916.

HARROWER, K. M. 1974. Survival and regeneration of Leptosphaeria (Septoria) nodorum. Trans. Br. mycol. Soc. 65: 7-18.

JAMES, W. C. 1974. Assessment of plant diseases and crop losses. Ann. Rev. Phytopathol. 12: $27-48$.

- \& TENG, P. S. 1979. The quantification of production constraints associated with plant diseases. Appl. Biol. 4: 201-267.

JENKYN, J. F. \& KING, J. E. 1977. Observations on the origins of Septoria nodorum infection of winter wheat. Plant pathol. 26: 153-160.

JONES, D. G. \& ODEBUNMI, K. 1971. The epidemiology of Septoria tritici and S. nodorum. IV The effects of inoculation at different growth stages and on different plant parts. Trans. Br. mycol. Soc. 56: $281-288$.

- \& ROWLING, R. D. W. 1976. The reaction of two spring wheat varieties exposed to epidemics of Septoria nodorum and S. tritici of varying intensity and duration. J. agric. Sci, Camb. 87: 401-406.

KARJALAINEN, R. \& LAITINEN, A. 1982. Screening for resistance of spring wheat to Septoria nodorum. Nordisk jordbruksforskning 64: 232-233.

- \& LAITINEN, A. \& JUUTI, T. 1983. Susceptibility of spring wheat cultivars to Septoria nodorum. J. Scient. Agric. Soc. Finl. 55: 315-332.

KING, J. E. 1977. Surveys of diseases of winter wheat in England and in Wales 1970-1975. Plant Pathol. 26: $8-20$.

LI, C. C. 1975. Path-analysis - a primer. The Boxwood Press, California.

LUPTON, F. G. H. 1982. Recent advances in cereal breeding. Neth. J. agric. Sci 30: 11-23.

MELVILLE, S. C. \& JEMMET, J. L. 1971. The effect of glume blotch on yield of winter wheat. Plant Pathol. 20: 14-17. 
NELSON, L. R., HOLMES, M. R. \& CUNFER, B. M. 1976. Multiple regression of accounting for wheat yield reduction by Septoria nodorum and other pathogens. Phytopath. 66: 375-379.

OBST, A. 1977. Untersuchungen zur Epidemiologie, Schadwirkungen und Prognose der Spelzenbräune (Septoria nodorum) des Weizens. Bayr. Landw. Jb. 54: 72-117.

RAJARAM, S. \& DUBIN, H. J. 1977. Avoiding genetic vulnerability in semi-dwarf wheats. Ann. N. Y. Acad. Sci 287: 243-254.

SAARI, E. E. \& WILCOXSON, R. D. 1974. Plant disease situation of high yielding dwarf wheats in Asia and Africa. Ann. Rev. Phytopath. 12: 49-68.

SCHAREN, A. L., SCHAEFFER, G. W., KRUPINSKY, J. M. \& SHARPE, F. T. Jr. 1975. Effects of flag leaf axial lesions caused by Septoria nodorum on ${ }^{14} \mathrm{C}$ translocation and yield of wheat. Physiol. Plant pathol. 6: 193-198.

— \& TAYLOR, J. M. 1968. CO2 assimilation and yield of Little Club wheat infected by Septoria nodorum. Phytopath. 58: 447-451.

SCOTT, P. R. \& BENEDIKZ, P. W. 1977. Field techniques for assessing the reaction of winter wheat cultivars to Septoria nodorum. Ann. appl. Biol. 85: 345-358.

SHIPTON, W. A. 1968. The effect of Septoria diseases on wheat. Aust. J. Exp. Agric. Anim. Husb. 8: 89-93.

- , BOYD, W. R. J., ROSIELLE, A. A. \& SHEARER, B. J. 1971. The common Septoria diseases of wheat. Bot. Rev. 37: 231-262.

SMEDEGAARD-PETERSEN, V. 1982. The effects of defence reactions on the energy balance and yield of resistant plants. In: Active Defence Mechanisms in Plants (ed. WOOD, R. K. S.), pp. 299-315. Plenum Press, New York, London.

SPIERZ, J. H. J. 1973. Effects of successive applications of Maneb and Benomyl on growth and yield of five wheat varieties of different heights. Neth. J. agric. Sci. 21: 282-296.

TENG, P. S. \& GAUNT, R. E. 1980-81. Modelling systems of disease and yield loss in cereals. Agricultural systems 6: 131-154.

WAFFORD, J. D. \& WHITBREAD, R. 1978. Effects of inoculation with Septoria nodorum on yield and yield components of spring wheats. Ann. appl. Biol. 90: 323-328.

- 1976. Effects of leaf infection by Septoria nodorum Berk. on the translocation of ${ }^{14} \mathrm{C}$-labelled assimilates in spring wheat. Ann. Bot. 40: 83-90.

WILLIAMS, W. \& JONES, D. G. 1972. The epidemiology of Septoria nodorum and S. tritici. VI Effects of time of initial infection on disease development and grain yield in spring wheat. Trans. Br. mycol. Soc. 59: 273-283.

WOOLHOUSE, H. W. 1981. Crop physiology in relation to agricultural production: the genetic link. In: Physiological Processes Limiting Plant productivity (ed. JOHNSON, C. B.), pp. 1-21. Butterworths, London.

Ms received June 6, 1983. 


\title{
Septoria nodorum Berk. -sienen vaikutus vehnän satoon ja sato- komponentteihin.
}

\author{
Reijo Karjalainen
}

Kasvipatologian ja Kasvinjalostustieteen laitos, Helsingin yliopisto, 00710 Helsinki 71

\section{Aino Laitinen ja Tapio Juuti}

Hankkijan kasvinjalostuslaitos, 04300 Hyrylä.

Vehnän lehti- ja tähkävioituksen aiheuttajaa Septoria nodorumia Berk. tutkittiin kahdessa kokeessa Hankkijan kasvinjalostuslaitoksen Anttilan koetilalla. Ensimmäisessä kokeessa Hankkijan Taava-lajiketta saastutettiin keinotekoisesti alhaisella itiömäärällä. Tulokset osoittivat taudin alentavan jyväsatoa $10 \%, 1000$-siemen painoa $14 \%$ ja hehtolitran painoa $5,7 \%$. Torjunta-ainekäsittelyt lisäsivät jyväsatoa ja satokomponentteja.

Toisessa kokeessa selvitettiin 28 kevätvehnälajikkeen tai -linjan taudinankaruuden ja satotappion välistä korrelaatiota. Alustavat tulokset osoittivat, että taudinankaruus ei aina ollut suorassa yhteydessä sadonalennukseen, vaan eräät alttiit lajikkeet, kuten Luja ja Hankkijan Ulla, kestivät tautia hyvin, kun taas kohtalaisen kestävillä lajikkeilla, kuten Kadett ja Drabant, tauti alensi satoa huomattavasti. Tutkimuksesta ilmenee, että Septoria nodorum -sieni aiheuttaa kohtalaisen runsaana esiintyessään merkittäviä sato- ja laatutappioita. 